\title{
Pileflebitis por diverticulitis aguda complicada
}

Pylephlebitis complicating acute diverticulitis

María del Carmen Azorín Samper ${ }^{1}$, María Dolores Ruiz Carmona ${ }^{2}$, Félix Checa Ayet $^{3}$

DOI 10.31837/cir.urug/4.1.5

Recibido: 2 de agosto de 2019

Aceptado: 13 de febrero de 2020

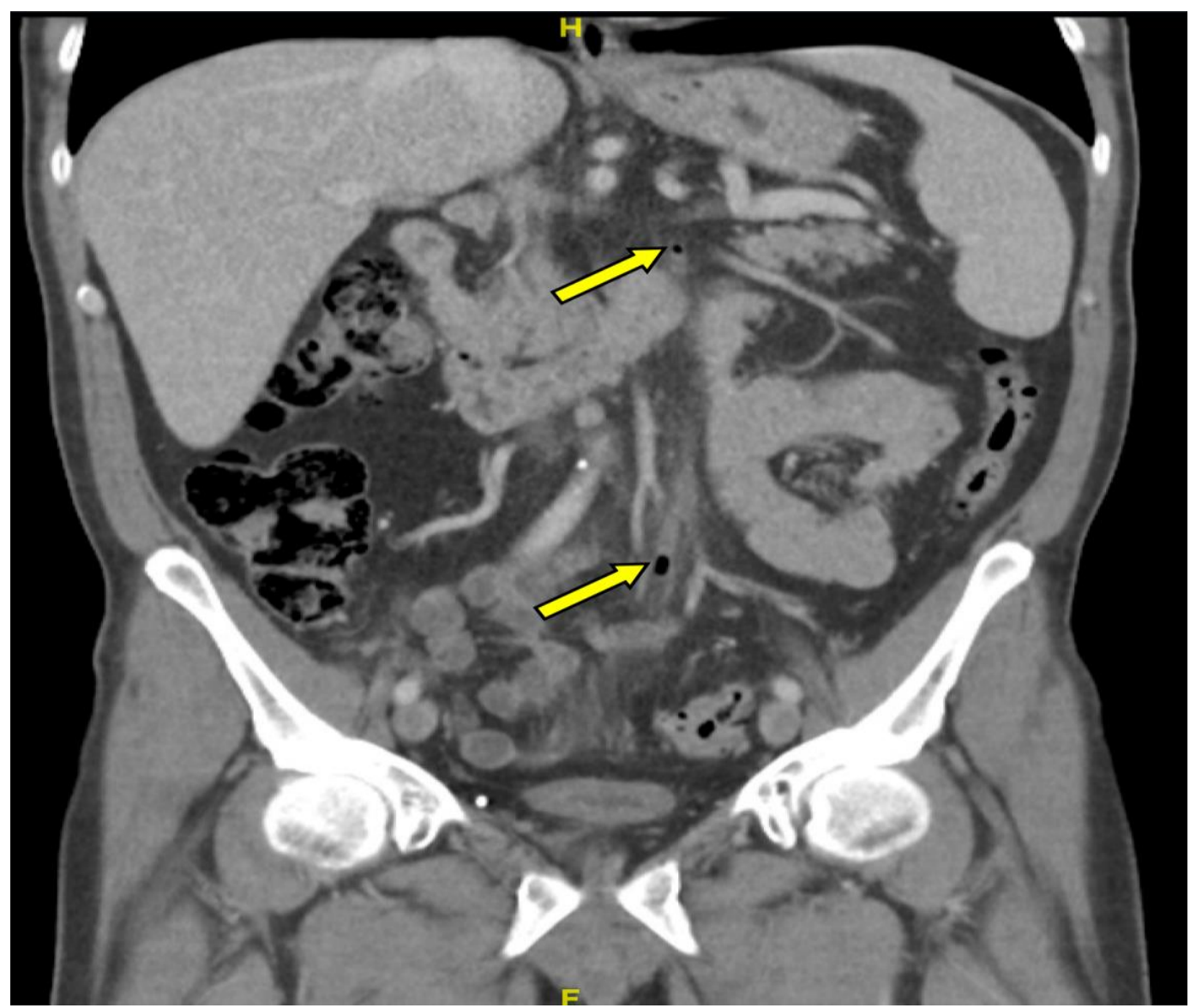

Figura 1. Pileflebitis en diverticulitis aguda complicada

1,2,3 Departamento de Sagunto. Institución: Hospital de Sagunto. Servicio Cirugía General y del Aparato Digestivo. Sagunto (Valencia), España. mcazosam16@gmail.com 
Varón de 60 años con antecedente de apendicectomía y diverticulosis de colon. Acudió al servicio de Urgencias por un cuadro de malestar general, fiebre, náuseas y vómitos de dos días de evolución. A la exploración, abdomen blando y depresible, doloroso en fosa ilíaca izquierda.

La analítica reveló neutrofilia, elevación de PCR y procalcitonina. Además, se obtuvieron hemocultivos positivos para Escherichia Coli.

El TC abdómino-pélvico mostró diverticulitis aguda complicada con microperforación local contenida e imágenes de burbujas aéreas intravasculares a nivel de vena hemorroidal superior y vena mesentérica inferior muy cercanas a su desembocadura a territorio esplénico (Figura 1).

Se le ingresó para tratamiento médico con antibioterapia intravenosa, siendo la evolución favorable, con alta domiciliaria al sexto día.

\section{Diagnóstico:}

Pileflebitis por diverticulitis aguda complicada. 